\title{
THE SECOND STEP IN THE CONSTRUCTION OF A STIGMA SCALE OF EPILEPSY
}

\author{
Priscila C.B. Salgado, ${ }^{1,2}$, Paula T. Fernandes ${ }^{1,2}$, Ana Lúcia A. Noronha ${ }^{1,2}$, \\ Fernanda D. Barbosa', Elisabete A.P. Souza' ${ }^{1}$ Li M. Li ${ }^{1,2}$
}

\begin{abstract}
Rationale: The issue of stigmatization is one of the most common psychosocial problems faced by people with epilepsy. Purpose: A second step towards the development of a scale to measure epilepsy stigma. Method: We applied a closed questionnaire to 12 patients and 32 relatives from the Epilepsy Outpatient Clinic at the University Hospital of Campinas. Results: The results are grouped in three main domains: medical, social and personal areas. Medical: the subjects did not know exactly what epilepsy is or how it is caused; nonetheless they know how to treat it. Social: the most important areas that people with epilepsy are discriminated are at work and social relationships. Patients also complained about their lack of freedom and limits on re creation activities. Personal Area: subjects apparently have the same feelings and thoughts about epilepsy and seizures. Conclusion: This study analyzed the most common aspects presented in the questionnaire to assess epilepsy stigma for the Brazilian culture which are the base to the elaboration of a stigma scale of epilepsy.
\end{abstract}

KEY WORDS: stigma, epilepsy, scale, quality of life, seizures.

\section{O segundo passo para a construção de uma escala de estigma na epilepsia}

RESUMO - Introdução: O estigma tem sido projetado como um dos problemas sociais mais comuns enfrentados por pessoas com epilepsia. Objetivo: Este estudo representa o segundo passo no desenvolvimento da escala para mensurar estigma na epilepsia. Método: O questionário foi aplicado em 12 pacientes e 32 familiares, entrevistados no Ambulatório de Epilepsia do Hospital das Clínicas, UNICAMP. Resultados: Os resultados estão agrupados nas três principais áreas: médica, social e pessoal. Médica: os sujeitos mostraram não ter informação suficiente ou adequada sobre epilepsia e crises, o que não aconteceu com relação ao tratamento. Social: o trabalho e as relações sociais apareceram como os aspectos de maior discriminação na epilepsia. Os pacientes também ressaltaram a falta de liberdade e restrição de atividades de lazer como aspectos bastante prejudicados. Área pessoal: todos os sujeitos aparentemente têm os mesmos sentimentos e pensamentos sobre epilepsia e crises epilépticas. Conclusão: Este estudo analisou os aspectos mais comuns apresentados no questionário para avaliar o estigma na epilepsia na cultura brasileira, os quais serão a base da elaboração da escala de estigma na epilepsia.

PALAVRAS-CHAVE: estigma, epilepsia, escala, qualidade de vida, crises epilépticas.

Epilepsy is a common neurological condition that affects the psychological adjustment and the quality of people's life and therefore, reveals a high incidence of fears, misunderstanding and stigma ${ }^{1,2}$. The social and psychological consequences of epilepsy are numerous. Patients often describe social stigma and the fear of being discriminated ${ }^{3}$. The issue of stigmatization is one of the most common psychosocial problems faced by people with epilepsy ${ }^{4-9}$. The stigmatization may lead to social withdrawn, problems at work and home, and economic difficulties.

Awareness about epilepsy is usually very low across the world. This can often lead to public discrimination and exclusion of people with epilepsy, as well as inappropriate treatment ${ }^{10}$. The identification of the people with epilepsy's needs and the promotion of public and professional education about this condition would offer to the patient a $g$ reater quality of life in terms of feeling better. It is apparent that medical management of epilepsy alone is not always enough to control its psychological consequences. Services that enable people to deal with negative reactions and which facilitate a realistic perception of the limitations imposed by the

${ }^{1}$ Department of Neurology, State University of Campinas (UNICAMP), Campinas SP, Brazil; '2Department of Psychology and Education, Assistência à Saúde de Pacientes com Epilepsia (ASPE), Campinas, SP Brazil.

Received 19 August 2004, received in final form 14 December 2004. Accepted 16 February 2005

Dr. Li Min Li - Department of Neurology / UNICAMP - Cx. Postal 6111 - 13083-970 Campinas SP - Brasil. E-mail: limin@fcm.unicamp.br or li@aspebrasil.org - Site: http://www.aspebrasil.org 
condition may contribute substantially to the reduction of stigma and the improvement of quality of life ${ }^{11}$.

Our former study ${ }^{12}$ has discussed the importance of creating a specific instrument to assess epilepsy stigma for the Brazilian culture. The first step was an exploratory study towards elaboration of a stigma scale based on results from a comprehensive review on this theme to conceptualize the main domains of epilepsy stigma. Three main domains were observed: medical, personal and social. The first open questionnaire was important to raise the first reactions about the concepts of epilepsy and stigma ${ }^{12}$. This study represents a second step towards the development of a scale to measure epilepsy stigma. We are now looking for the most common aspects presented in the questionnaire, which are going to be used in the elaboration of the stigma scale of epilepsy.

\section{METHOD}

Subjects -This study focused on patients and their relatives from the Epilepsy Outpatient Clinic at the University Hospital of Campinas, Brazil. Twelve adult patients and thirty-two relatives were interviewed. There were 13 men and 31 women.

Instruments - The questionnaires used in this study came from the open questionnaire of our former study ${ }^{12}$. The questionnaire used for the community had 16 closed questions about the medical (4 questions), social (10 questions) and personal (2 questions) areas. The patients' questionnairehad four additional questions in the social and three in the personal area. The answers were categorized and could have multiple responses.

Assessment-Patients and relatives were interviewed by psychologists (PTF, PCBS, FDB) at the Epilepsy Outpatient Clinic of University Hospital of State University of Campinas. The questionnaires were individually applied, and the condition was the same for all the subjects. The application took about 20 minutes. All subjects had signed the Informed Consent, approved by the Ethics Committee of Unicamp (number 064/2002).

\section{RESULTS}

The mean age of the patients was 27 years ( $r a n-$ ge from 12 to 42). The mean age of the relatives was 47 years (range from 27 to 66 ). Half of the interviewers had not completed elementary school.

The results are grouped in three main domains: medical, social and personal areas. The most common answers given by patients and their relatives during the entire questionnaire are shown on Tables 1,2 and 3 . The whole questionnaire is presented on these tables, divided in domains. The answers showed are the most common ones that mean the ones with a frequency higher than $50 \%$, which are going to be the base to the scale elaboration.

The main findings for each domain are the following: i) in the medical area both patients and relatives did not know exactly what epilepsy is or how is it caused, nonetheless they know how to treat it. ii) in the social area both patients and relatives agree that the most important areas that people with epilepsy face difficulties and are discriminated are at work and social relationships. Patients seem not to understand why this discrimination occurs, but their relatives said they would never hire anyone with epilepsy because of prejudice, fear, risks, and difficulty to deal with seizures. Patients also complained about their lack of freedom and limitations on re c reation activities. iii) in the personal area patients and relatives apparently have the same feelings and thoughts about epilepsy and seizures.

\section{DISCUSSION}

This study, as a second step to the elaboration of a stigma scale, focused on the most common aspects presented in this questionnaire to assess epilepsy stigma for the Brazilian culture. The results showed that patients and their relatives did not have enough or adequate information about epilepsy and seizures, which may be a factor leading to stigma. Patients seem to feel that epilepsy disturbs their lives in some aspects that are not recognized or in-

Table 1. Medical area.

\begin{tabular}{lll}
\hline Questions & Patients & Relatives \\
\hline What is epilepsy? & Convulsion, headache, disease & Convulsion, headache, faint \\
What are the causes of epilepsy? & I do not know, trauma & I do not know \\
$\begin{array}{l}\text { What do you know about the types of } \\
\text { treatment for epilepsy? }\end{array}$ & Medication, exams, surgery & Medication, exams \\
How did you get this information? & Doctors, school & Doctors, television \\
\hline
\end{tabular}


Table 2. Social area.

\begin{tabular}{|c|c|c|}
\hline Questions & Patients & Relatives \\
\hline Do you know anyone who has epilepsy? & - & Yes \\
\hline $\begin{array}{l}\text { What would you do if you see someone having a } \\
\text { seizure? What people do when you have a seizure?* }\end{array}$ & Help, shock & Help \\
\hline Which are the difficulties faced by people with epilepsy? & Work, no freedom & Social relationships, work \\
\hline $\begin{array}{l}\text { In what situations do you think a person with } \\
\text { epilepsy is discriminated? }\end{array}$ & $\begin{array}{l}\text { Religion, social relationships, } \\
\text { work, recreation activities }\end{array}$ & $\begin{array}{l}\text { Work, social relationships, } \\
\text { most of the situations }\end{array}$ \\
\hline $\begin{array}{l}\text { Do you think it is more difficult to a person with } \\
\text { epilepsy to find work? Why? }\end{array}$ & Yes. Prejudice, risks & Yes. Prejudice, risks \\
\hline $\begin{array}{l}\text { What is your religion and what does it think } \\
\text { about epilepsy? }\end{array}$ & $\begin{array}{l}\text { Catholic. It is a neurological } \\
\text { condition, I do not know }\end{array}$ & $\begin{array}{l}\text { Catholic. It is a neurological } \\
\text { condition, I do not know }\end{array}$ \\
\hline $\begin{array}{l}\text { Would you hire someone with epilepsy to work } \\
\text { at your house? }\end{array}$ & $\begin{array}{l}\text { Yes. They are normal } \\
\text { people, they have the same } \\
\text { rights }\end{array}$ & $\begin{array}{l}\text { No. Prejudice, fear, risks, } \\
\text { difficulty to deal with } \\
\text { seizures }\end{array}$ \\
\hline Would you marry someone with epilepsy? Why? & $\begin{array}{l}\text { Yes. They have the same } \\
\text { rights, they are ordinary } \\
\text { people }\end{array}$ & $\begin{array}{l}\text { Yes. They have the same } \\
\text { rights, they are ordinary } \\
\text { people }\end{array}$ \\
\hline Do you think people with epilepsy can drive? Why? & No. Risks & No. Risks \\
\hline $\begin{array}{l}\text { Would you allow some close to you to have a } \\
\text { friend with epilepsy? Why? }\end{array}$ & $\begin{array}{l}\text { Yes. They have the same } \\
\text { rights, they are ordinary } \\
\text { people }\end{array}$ & $\begin{array}{l}\text { Yes. They have the same } \\
\text { rights, they are ordinary } \\
\text { people }\end{array}$ \\
\hline Do you feel your doctor take care of you? * & Yes. & - \\
\hline $\begin{array}{l}\text { What do you do when you feel you are about to } \\
\text { have a seizure?*}\end{array}$ & $\begin{array}{l}\text { Sit or lay down, get } \\
\text { nervous, nothing }\end{array}$ & - \\
\hline Do you tell people about your epilepsy? * & Yes & - \\
\hline
\end{tabular}

*only for patients

Table 3. Personal area.

\begin{tabular}{lll}
\hline Questions & Patients & Relatives \\
\hline How do you fell when you see a seizure? & Afraid, sad, nervous & Sad, afraid, pity \\
How do you fell when you have a seizure? * & & Insecure, sad, worried, \\
How do you think people with epilepsy fell? & Insecure, sad, worried, & shamed \\
How do you feel among others? * & normal & - \\
$\begin{array}{l}\text { What do you guess people think of you when you have a } \\
\text { seizure?* }\end{array}$ & $\begin{array}{l}\text { I am not healthy, } \\
\text { prejudice, fear, pity }\end{array}$ & \\
\hline
\end{tabular}

*only for patients.

terpreted in a different way by their family. This was clear in the Social Domain, whereas people with epilepsy would hire someone with epilepsy, because they view themselves as normal people who have the same rights. However, their relatives disagree and pointed out prejudice, fear, possible risks and difficulties to deal with seizures in a working environment. These answers in part reflect overprotection, a common pattern observed in pediatric groups, but also it can be a realistic view of patients with frequent and severe seizure in one extreme to pure simple prejudice in the other. 
Attention should be paid for the fact that society was represented in this study by patients' relatives, that is, people who are used to live with "epileptics". We believe the wrong ideas about epilepsy and the discriminative feelings found in this study would be even stronger when taking the society as a whole.

In a psychological view, the judgment of "epileptics", based on inadequate information and beliefs, reinforces the feeling of impotence that patients have about their seizures and themselves. Because people with epilepsy have so often internalized society's devaluation of them, they do not think they can change the situation. Indeed, negative stereotypes of people with epilepsy have been so ingrained in the collective belief system that they have become an accepted part of many people's concept of the disorder ${ }^{13}$, including patients themselves. They may feel and be discriminated, but they do not believe in changing this situation. These aspects have a great impact on the felt stigma and make it difficult to distinguish felt and enacted stigma.

There has been an increasing recognition that seizures might be less disabling than their psychosocial correlates. It has been assumed that the main threat comes from "normal" people who, ignor a nt and apprehensive about what epilepsy is, tend to maintain social distance through discriminatory practices in both public and private spheres ${ }^{10}$.

Medical management of epilepsy clearly has impact on psychological outcome as well as stigma. Nevertheless, at this point, our objective was centered on perception of epilepsy by patients and society. The development of an instrument based on this study can provide a quantitative measurement of stigma, and then future researches involving stigma and others correlates, as epilepsy (age at seizures onset, seizures type and frequency, antiepileptic drugs, and others) and social (social and school level, civil status, and others) data can be analyzed.

In conclusion, the answers obtained in this study $p$ rovided a clue based on the specific domains ( $m e$ dical, social and personal) about felt and enacted stigma, however, a larger sample in a community can complement the understanding of stigma and shortlist the most important points to be used in a stigma scale of epilepsy.

\section{REFERENCES}

1. Fernandes PT, Souza EA. Identification of family variables in parents groups of children with epilepsy. Arq Neuropsiquiatr 2001;59:854-858.

2. Li LM, Sander JW. [National demonstration project on epilepsy in Brazil]. Arq Neuropsiquiatr 2003;61:153-156.

3. Leidy NK, Rentz AM, Grace E.M. Evaluating Health-related Quality of Life Outcomes in Clinical Trials of Antiepileptic Drug Therapy. Epilepsia 2004;39:965-977.

4. Baker GA, Brooks J, Buck D, Jacoby A. The stigma of epilepsy: a European perspective. Epilepsia 2000;41:98-104.

5. Baker GA, Nashef L, van Hout BA. Current issues in the management of epilepsy: the impact of frequent seizures on cost of illness, quality of life, and mortality. Epilepsia 1997;38(Suppl 1):S1-S8.

6. Baker GA, Jacoby A, Chadwick DW. The associations of psychopathology in epilepsy: a community study. Epilepsy Res 1996;25:29-39.

7. Jacoby A. Felt versus enacted stigma: a concept revisited. Evidence from a study of people with epilepsy in remission. Soc Sci Med 1994;38:269-274.

8. Placencia M, Farmer PJ, Jumbo L, Sander JW, Shorvon SD. Levels of stigmatization of patients with previously untreated epilepsy in northern Ecuador. Neuroepidemiology 1995;14:147-154.

9. Ratsepp M, Oun A, Haldre S, Kaasik AE. Felt stigma and impact of epilepsy on employment status among Estonian people: exploratory study. Seizure 2000;9:394-401.

10. Scambler G, Hopkins A. Generating a model of epileptic stigma: the role of qualitative analysis. Soc Sci Med 1990;30:1187-1194.

11. Ryan R, Kempner K, Emlen AC. The stigma of epilepsy as a self-concept. Epilepsia 1980;21:433-444.

12. Fernandes PT, Salgado PC, Noronha ALA, Barbosa FD, Souza EA, Li LM. Stigma Scale of Epilepsy: conceptual issues. J Epilep Clin Neuropshysiology 2004;10:213-218.

13. McLin WM, de Boer HM. Public perceptions about epilepsy. Epilepsia 1995;36:957-959. 